\title{
Foliar application of nitrogen, potassium and magnesium, and pineapple yield and quality ${ }^{1,2}$
}

\author{
Antonio Vélez-Ramos ${ }^{3}$ and Jorge Borges ${ }^{4}$
}

\begin{abstract}
A field experiment was conducted on a Bayamón soil to evaluate the effect of foliar applications of nitrogen, potassium and magnesium on the yield and quality of pineapple cultivar Red Spanish. The application of $\mathbf{3 9 2}$ $\mathrm{kg} / \mathrm{ha}$ of $\mathrm{K}$ and $224 \mathrm{~kg} / \mathrm{ha}$ of $\mathrm{Mg}$ resulted in a significant increase in fruit yield over the lowest $\mathrm{K}-\mathrm{Mg}$ application rate $(224 \mathrm{~kg} / \mathrm{ha}$ of $\mathrm{K}$ and no $\mathrm{Mg})$ in the plant crop. Increasing N from 224 to 392 and to $784 \mathrm{~kg} / \mathrm{ha}$ did not significantly increase fruit yield but reduced brix and acidity and increased $\mathrm{pH}$ of the fruit. A significant increase of $6,572 \mathrm{~kg} / \mathrm{ha}$ of pineapple fruits was obtained in the ratoon crop with the application of $520 \mathrm{~kg} / \mathrm{ha}$ of $\mathrm{K}$ and $74 \mathrm{~kg} / \mathrm{ha}$ of $\mathrm{Mg}$. Nitrogen levels had no significant effect on pineapple fruit yield and quality in the ratoon crop. The average length and width of the fruit and core diameter increased significantly as magnesium applications increased. Nitrogen and potassium content of the D-leat of 4-month-old plants was adequate, but rather low in 10-month-old plants, regardless of $\mathrm{N}-\mathrm{K}$ treatment. In the ratoon (22- and 26-month) leat nitrogen was adequate, but potassium was low. Potassium treatments had tittle effect on leaf potassium content. Calcium and magnesium content ran low throughout the crop cycle, especially in the ratoon crop.
\end{abstract}

Key words: Ananas comosus, foliar fertilization, pineapple yield, pineapple quality

\section{RESUMEN}

Efecto de aplicaciones foliares de nitrógeno, potasio y magnesio sobre el rendimiento y la calidad de la piña

Se estableció un experimento de campo en un suelo de la serie Bayamón para evaluar el efecto de niveles de nitrógeno, potasio y magnesio en aplicaciones foliares sobre el rendimiento y la calidad de la fruta de piña (Ananas comosus (L.) Merr.) cultivar Española Roja. La combinación de $392 \mathrm{~kg} /$ ha de $\mathrm{K}$ y $224 \mathrm{~kg} / \mathrm{ha}$ de $\mathrm{Mg}$ resultó en un aumento significativo de $8,349 \mathrm{~kg} /$ ha de frutas al compararlo con la aplicación de $224 \mathrm{~kg} / \mathrm{ha}$ de $\mathrm{K}$ y cero $\mathrm{Mg}$ en la cosecha de plantilla. El incrementar el nitrógeno de 224 a 392 y $784 \mathrm{~kg} / \mathrm{ha}$ no aumentó el rendimiento de frutas en forma significativa, pero redujo el brix y la acidez y aumentó el $\mathrm{pH}$ de la fruta. La aplicación de $520 \mathrm{~kg} / \mathrm{ha}$ de $\mathrm{K}$ y $74 \mathrm{~kg} / \mathrm{ha}$ de $\mathrm{Mg}$ produjo un aumento significativo de $6,572 \mathrm{~kg} / \mathrm{ha}$ de frutas

'Manuscript submitted to Editorial Board 5 February 1992.

2Thanks are expressed to the Pineapple Program of the Land Authority of P.R., especially to the members of the Research Division for their kind assistance and collaboration during the study.

${ }^{3}$ Agronomist, Department of Agronomy and Soils.

"Director, Research Division, Pineapple Program, Land Authority of P.R., Department of Agriculture. 
en la cosecha de retoño. En el retoño, el aumento en el nivel de nitrógeno no tuvo efecto significativo en el rendimiento y la calidad de la fruta. El largo y ancho promedio de la fruta y el diámetro del corazón aumentaron significativamente al aumentar el nivel de nitrógeno. El contenido de nitrógeno y potasio en la hoja-D fue adecuado en plantas de cuatro meses de edad pero fue bajo para plantas de 10 meses de edad, independientemente de la cantidad de nitrógeno y potasio aplicada. En el ciclo de retoño (22 y 26 meses) el contenido de nitrógeno en la hoja fue adecuado pero el contenido de potasio fue bajo. Los niveles de potasio aplicados no tuvieron efecto significativo sobre el contenido de potasio en la hoja. El contenido de calcio y magnesio en la hoja se mantuvo bajo a través del estudio, especialmente en las plantas más viejas (retoño).

\section{INTRODUCTION}

According to Cooke (1949), "Anyone can grow pineapples successfully on virgin land, but it requires real knowledge to plant pineapples repeatedly and successfully on the same piece of land." Pineapple demands large quantities of soil nutrients, especially nitrogen and potassium for optimum yields. Not only the relative amount of a specific nutrient is important, but also the ratio of selected nutrients. Thus, an increase in nitrogen availability may result in an increase in the level of potassium in the tissues and consequently immobilization (Marchal et al., 1970). The absorption of magnesium is influenced by both nitrogen and potassium content in the soil (Siders and Young; 1945; 1946). According to Molinier (quoted in Py et al., 1987), magnesium fertilizers are often applied in Hawaii in enough quantity to

TABLE 1.-Fertilizer treatments.

\begin{tabular}{|c|c|c|c|c|c|c|c|c|}
\hline \multicolumn{3}{|c|}{ Plant Crop } & \multicolumn{3}{|c|}{ Ratoon } & \multicolumn{3}{|c|}{ Plant and Ratoon Combined } \\
\hline$N$ & $\mathrm{~K}_{2} \mathrm{O}$ & $\mathrm{MgO}$ & $N$ & $\mathrm{~K}_{2} \mathrm{O}$ & $\mathrm{MgO}$ & $N$ & $\mathrm{~K}_{2} \mathrm{O}$ & $\mathrm{MgO}$ \\
\hline \multirow[t]{4}{*}{224} & 224 & 0 & 57 & 75 & 0 & 281 & 299 & 0 \\
\hline & & 56 & & & 37 & & & 93 \\
\hline & & 112 & & & 74 & & & 186 \\
\hline & & 224 & & & 148 & & & 372 \\
\hline \multirow[t]{4}{*}{392} & 392 & 0 & 200 & 220 & 0 & 592 & 612 & 0 \\
\hline & & 56 & & & 37 & & & 93 \\
\hline & & 112 & & & 74 & & & 186 \\
\hline & & 224 & & & 148 & & & 372 \\
\hline \multirow[t]{4}{*}{784} & 784 & 0 & 483 & 520 & 0 & 1267 & 1304 & 0 \\
\hline & & 56 & & & 37 & & & 93 \\
\hline & & 112 & & & 74 & & & 186 \\
\hline & & 224 & & & 148 & & & 372 \\
\hline
\end{tabular}


ensure a $\mathrm{K}: \mathrm{Mg}$ ratio of 5:1. Well documented information is available on the influence of cations $\mathrm{K}, \mathrm{Ca}$ and $\mathrm{Mg}$ on pineapple fruit yield (MartinPrevel, 1961.a), on fruit quality (Martin-Prevel, 1961b) and on the mineral content of the D-leaf (Martin-Prevel, 1961c).

In Puerto Rico, Samuels et al. (1955; 1958), González-Tejera (1975) and González-Tejera et al. (1974) studied the effect of levels and sources of nitrogen and potassium fertilizers on pineapple fruit yield and quality. Hernández-Medina $(1961 ; 1964)$ reported beneficial effects of magnesium on pineapple growth and production. These field trials were with side-dressed fertilizer applications and low planting densities. Current production practices in Puerto Rico include high plant populations (more than 60,000 plants per hectare) and multiple foliar fertilizer sprays. There is no information available on pineapple fertilizer requirements under these production practices. The present investigation was undertaken in order to gather information toward this end.

\section{MATERIALS AND METHODS}

A field trial was conducted in cooperation with the Pineapple Program of the Land Authority of Puerto Rico on Palo Alto farm. The soil was classified as Bayamón (Typic Haplorthox, clayey, oxidic, isohyperthermic). It had been planted to pineapple for more than 50 consecutive years. Laboratory soil analyses indicated low exchangeable $\mathrm{K}, \mathrm{Ca}$ and $\mathrm{Mg}$, and a $\mathrm{pH}$ of 4.3

For the plant crop, the experimental design used was a randomized complete block with three replications. The treatments were analyzed in split-plots with nitrogen levels (224, 392 and $784 \mathrm{~kg} / \mathrm{ha}$ ) assigned to the main plots, and the 12 factorial combinations of $\mathrm{K}-\mathrm{Mg}$ to the subplots (Table 1). Potassium was applied at rates of 224,392 and $784 \mathrm{~kg} /$ ha as $\mathrm{K}_{2} \mathrm{O}$. Magnesium was applied at 0, 56, 112 and $224 \mathrm{~kg} / \mathrm{ha}$ as $\mathrm{MgO}$. The main plots contained 12 continuous sub-plots consisting of four double rows $71 \mathrm{~cm}$ apart, $6.1 \mathrm{~m}$ long with $51 \mathrm{~cm}$ between rows. Plant distance within the row was $30 \mathrm{~cm}$, thus making a stand of 51,000 plants per hectare. There were $1.53-\mathrm{m}$ alleys between sub-plots. Slips of Red Spanish cultivar were planted in December 1987.

All plots received a pre-planting fertilizer application consisting of $1,120 \mathrm{~kg} / \mathrm{h}$ a of a formula $12-6-10$ equivalent to 134,67 and $112 \mathrm{~kg} / \mathrm{ha}$ of $\mathrm{N}, \mathrm{P}_{2} \mathrm{O}_{5}$ and $\mathrm{K}_{2} \mathrm{O}$, respectively. Ten monthly foliar applications of urea, $\mathrm{K}_{2} \mathrm{SO}_{4}$ and $\mathrm{MgSO}_{4}$ were made to supply additional $\mathrm{N}, \mathrm{K}_{2} \mathrm{O}$ and $\mathrm{MgO}$ according to the fertilizer treatment differentials in the plant and ratoon crops. Foliar treatment applications were made with a $20 \mathrm{~L}$ Knapsack sprayer. In the ratoon crop the foliar sprays were reduced to six 


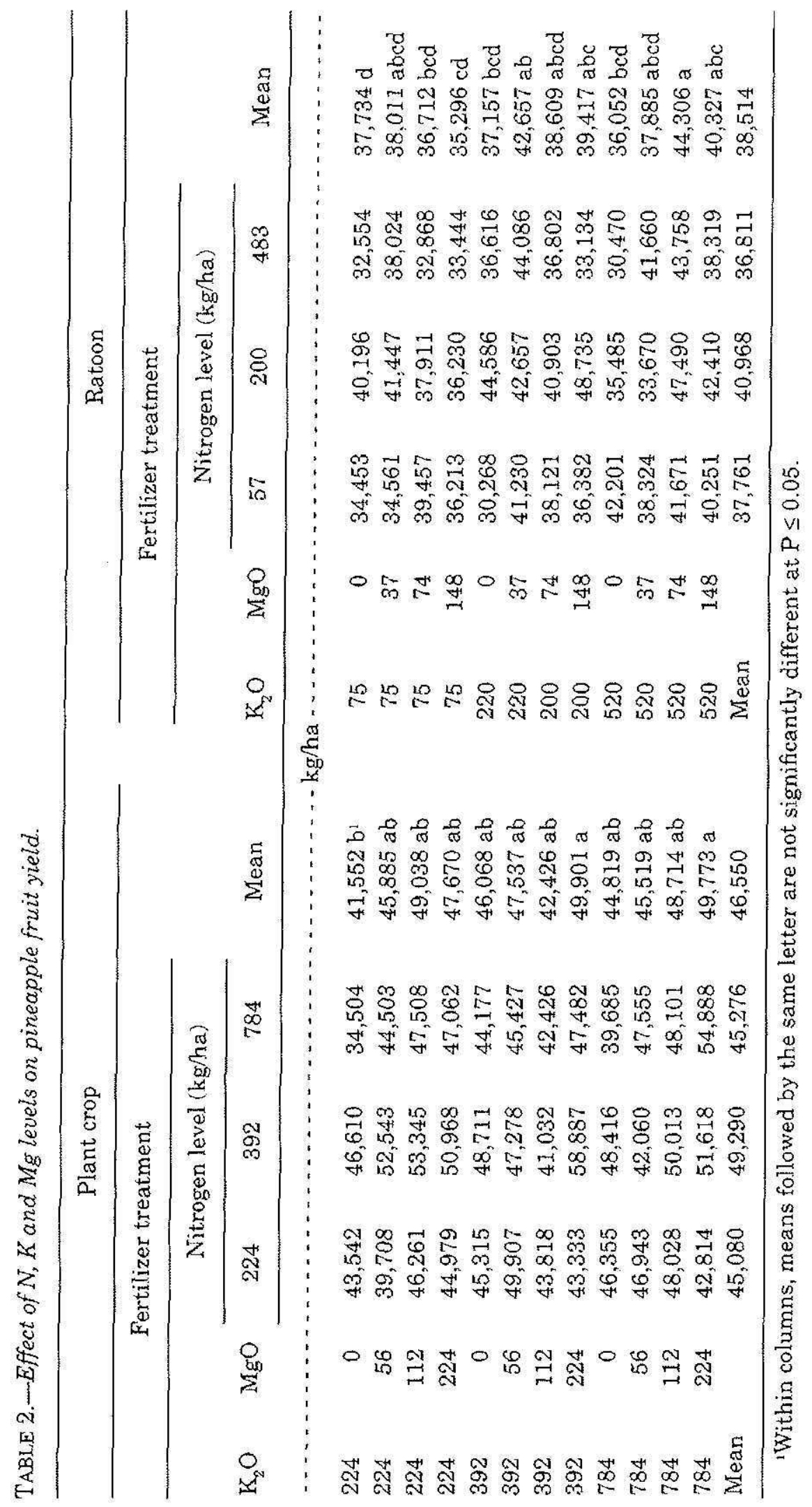


TABLE 3.-Effect of treatments on pineapple fruit quality.

\begin{tabular}{|c|c|c|c|c|c|c|c|c|c|}
\hline \multicolumn{5}{|c|}{ Plant crop } & \multicolumn{5}{|c|}{ Ratoon } \\
\hline \multicolumn{2}{|c|}{ Fertilizer } & $\mathrm{pH}$ & Brix & Acidity & \multicolumn{2}{|c|}{ Fertilizer ${ }^{1}$} & $\mathrm{pH}$ & Brix & Acidity \\
\hline $\mathrm{kg} / \mathrm{ha}$ & & & & $\begin{array}{l}\text { Meq./ } \\
100 \mathrm{ml}\end{array}$ & \multicolumn{2}{|c|}{ kg/ha } & & & $\begin{array}{l}\text { Meq./ } \\
100 \mathrm{ml}\end{array}$ \\
\hline \multicolumn{10}{|c|}{ Nitrogen levels } \\
\hline \multicolumn{2}{|c|}{224} & $3.89 \mathrm{~b}^{2}$ & $16.3 \mathrm{a}$ & $463 \mathrm{a}^{2}$ & \multicolumn{2}{|c|}{281} & 3.71 & 15.8 & 522 \\
\hline & & $4.05 \mathrm{a}$ & $15.9 \mathrm{ab}$ & $401 a b$ & \multicolumn{2}{|c|}{592} & 3.71 & 15.9 & 537 \\
\hline & & $4.02 \mathrm{a}$ & $15.8 \mathrm{~b}$ & $381 \mathrm{~b}$ & \multicolumn{2}{|c|}{1267} & 3.71 & 15.2 & 594 \\
\hline \multicolumn{10}{|c|}{$\mathrm{K}_{2} \mathrm{O}$ and $\mathrm{MgO}$ levels } \\
\hline $\mathrm{K}_{2} \mathrm{O}$ & $\mathrm{MgO}$ & & & & $\mathrm{K}_{2} \mathrm{O}$ & $\mathrm{MgO}$ & & & \\
\hline 224 & 0 & 4.06 & 16.1 & $374 c^{2}$ & 299 & 0 & 3.66 & 15.8 & 553 \\
\hline 224 & 56 & 4.02 & 16.0 & $396 \mathrm{bc}$ & 299 & 93 & 3.71 & 15.2 & 546 \\
\hline 224 & 112 & 4.03 & 15.8 & $397 \mathrm{bc}$ & 299 & 136 & 3.67 & 15.9 & 533 \\
\hline 224 & 224 & 3.98 & 16.0 & $410 \mathrm{abc}$ & 299 & 372 & 3.70 & 16.0 & 561 \\
\hline 392 & 0 & 3.99 & 15.9 & $398 \mathrm{bc}$ & 612 & 0 & 3.67 & 15.7 & 565 \\
\hline 392 & 56 & 3.95 & 16.0 & $436 \mathrm{abc}$ & 612 & 93 & 3.73 & 15.5 & 549 \\
\hline 392 & 112 & 3.95 & 16.1 & $412 a b c$ & 612 & 136 & 3.69 & 15.7 & 528 \\
\hline 392 & 224 & 3.91 & 15.7 & $461 \mathrm{a}$ & 612 & 372 & 3.72 & 15.4 & 553 \\
\hline 784 & 0 & 3.97 & 16.0 & $422 \mathrm{abc}$ & 1304 & 0 & 3.73 & 15.7 & 549 \\
\hline 784 & 56 & 3.97 & 16.0 & $422 a b c$ & 1304 & 0 & 3.73 & 15.7 & 567 \\
\hline 784 & 112 & 3.96 & 15.9 & $445 a b$ & 1304 & 93 & 3.73 & 15.7 & 569 \\
\hline 784 & 224 & 4.02 & 16.2 & $429 a b c$ & 1304 & 372 & 3.73 & 15.9 & 540 \\
\hline
\end{tabular}

Total fertilizer applied for plant and ratoon crops.

${ }^{2}$ Within fertilizer and columns, means followed by the same letter are not significantly different at $\mathrm{P} \leq 0.05$.

monthly applications and the total $\mathrm{N}, \mathrm{K}$ and $\mathrm{Mg}$ applied was reduced proportionally.

D-leaf samples were collected at 4, 10,22 and 26 months after planting and analyzed for $\mathrm{N}, \mathrm{K}, \mathrm{Ca}$ and $\mathrm{Mg}$ content in the ash. The plant crop was harvested from June to July in 1989 and the ratoon crop from July to August in 1990. Fruit yield per plot was recorded. A sample of pineapple fruits from each plot was collected and analyzed for the $\mathrm{pH}$, brix and total acidity of the juice. Fruit length and width and fruit core diameter were measured.

\section{RESULTS AND DISCUSSION}

Increasing the level of nitrogen fertilization had no effect on fruit yield of the plant crop (Table 2). Mean fruit yield was $45,080 \mathrm{~kg} / \mathrm{ha}$ 
TABLE 4.-Effect of treatments on fruit characteristics.

\begin{tabular}{|c|c|c|c|c|c|c|c|c|c|}
\hline \multicolumn{5}{|c|}{ Plant crop } & \multicolumn{5}{|c|}{ Ratoon } \\
\hline \multicolumn{2}{|c|}{ Fertilizer } & Length & Width & Core & \multicolumn{2}{|c|}{ Fertilizer ${ }^{2}$} & Length & Width & Core \\
\hline \multicolumn{2}{|c|}{$\mathrm{kg} / \mathrm{ha}$} & $\cdots \cdots$ & $\cdots \mathrm{cm}-$ & $\ldots \ldots$ & $\mathrm{kg}$ & & $\cdots \cdots$ & $\cdots \mathrm{cm}$ & $\ldots \ldots$ \\
\hline \multicolumn{10}{|c|}{ Nitrogen levels } \\
\hline \multicolumn{2}{|c|}{224} & $12.3 b^{2}$ & $11.7 \mathrm{~b}$ & $1.79 \mathrm{~b}^{2}$ & \multicolumn{2}{|c|}{281} & 11.4 & 11.0 & 1.41 \\
\hline \multicolumn{2}{|c|}{392} & $13.3 \mathrm{a}$ & $15.9 \mathrm{a}$ & $1.84 a b$ & \multicolumn{2}{|c|}{592} & 11.5 & 11.0 & 1.43 \\
\hline \multicolumn{2}{|c|}{784} & $13.2 \mathrm{a}$ & $15.8 \mathrm{a}$ & $1.86 \mathrm{a}$ & 12 & & 11.4 & 11.0 & 1.43 \\
\hline \multicolumn{10}{|c|}{$K_{3} O$ and $\mathrm{MgO}$ levels } \\
\hline $\mathrm{K}_{2} \mathrm{O}$ & $\mathrm{MgO}$ & & & & $\mathrm{K}_{2} \mathrm{O}$ & $\mathrm{MgO}$ & & & \\
\hline 224 & 0 & 12.4 & 11.7 & 1.85 & 299 & 0 & 11.1 & 10.8 & $1.36 c^{2}$ \\
\hline 224 & 56 & 13.1 & 12.2 & 1.83 & 299 & 93 & 11.1 & 10.8 & $1.41 \mathrm{abc}$ \\
\hline 224 & 112 & 13.0 & 12.2 & 1.91 & 299 & 136 & 11.4 & 11.0 & $1.42 \mathrm{abc}$ \\
\hline 224 & 224 & 13.1 & 12.3 & 1.79 & 299 & 372 & 11.2 & 10.7 & $1.40 \mathrm{abc}$ \\
\hline 392 & 0 & 13.1 & 12.4 & 1.89 & 612 & 0 & 11.4 & 10.9 & $1.39 b c$ \\
\hline 392 & 56 & 13.0 & 12.4 & 1.91 & 612 & 93 & 11.7 & 11.1 & $1.46 \mathrm{ab}$ \\
\hline 392 & 112 & 12.8 & 12.0 & 1.90 & 612 & 136 & 11.5 & 11.0 & $1.42 \mathrm{abc}$ \\
\hline 392 & 224 & 13.3 & 12.4 & 1.51 & 612 & 372 & 11.5 & 11.1 & $1.42 \mathrm{abc}$ \\
\hline 784 & 0 & 12.8 & 12.0 & 1.89 & 1304 & 0 & 11.5 & 11.0 & $1.43 \mathrm{abc}$ \\
\hline 784 & 56 & 12.8 & 12.2 & 1.90 & 1304 & 93 & 11.9 & 11.3 & $1.46 \mathrm{ab}$ \\
\hline 784 & 112 & 13.1 & 12,4 & 1.89 & 1304 & 136 & 11.9 & 11.4 & $1.49 \mathrm{a}$ \\
\hline 784 & 224 & 12.5 & 12.2 & 1.89 & 1304 & 372 & 1.1 .3 & 11.0 & $1,41 \mathrm{abc}$ \\
\hline
\end{tabular}

'Total fertilizer applied for plant and ratoon crops.

2Within fertilizer and columns, means followed by the same letter are not significantly different at $\mathrm{P} \leq 0.05$.

when $224 \mathrm{~kg} / \mathrm{ha}$ of $\mathrm{N}$ was applied; $49,290 \mathrm{~kg} / \mathrm{ha}$ when $392 \mathrm{~kg} / \mathrm{ha}$ of $\mathrm{N}$ was applied; and $45,276 \mathrm{~kg} / \mathrm{ha}$ when $784 \mathrm{~kg} / \mathrm{ha}$ of $\mathrm{N}$ was applied. The highest fruit yield $(49,901 \mathrm{~kg} / \mathrm{ha}$ ) was obtained with the treatment combination of $392 \mathrm{~kg} / \mathrm{ha}$ of $\mathrm{K}$ and $224 \mathrm{~kg} / \mathrm{ha}$ of $\mathrm{Mg}$ but was only significantly higher than the yield obtained with $224 \mathrm{~kg} / \mathrm{ha}$ of $\mathrm{K}$ and no $\mathrm{Mg}$. The mean yield of these plots was $41,552 \mathrm{~kg} / \mathrm{ha}$, a difference of $8,349 \mathrm{~kg} / \mathrm{ha}$ of fruit.

No significant response to nitrogen increments was observed in the ratoon crop. The yield obtained with the application of $520 \mathrm{~kg} / \mathrm{ha}$ of $\mathrm{K}$ and $74 \mathrm{~kg} / \mathrm{ha}$ of $\mathrm{Mg}(44,306 \mathrm{~kg} / \mathrm{ha})$ was significantly higher than the yield of other $\mathrm{K}-\mathrm{Mg}$ treatments where no $\mathrm{Mg}$ was applied.

The lack of a more pronounced effect from $N$ and $K$ fertilizers on pineapple yield in this study may be explained on the basis of an unbalanced application of the two nutrients resulting in a higher supply of 
one nutrient and too little of the other. The antagonistic effect on the absorption and assimilation of $\mathrm{NH}_{4}$ and $\mathrm{K}$ ions is well documented (Teiwes and Gruneberg, 1963).

Table 3 presents the effect of the treatments on pineapple fruit quality. In the plant crop, the fruit juice $\mathrm{pH}$ increased with a nitrogen increment up to $392 \mathrm{~kg} / \mathrm{ha}$, but brix and total acidity were significantly reduced. In general, the higher fruit acidity was associated with the upper levels of $\mathrm{K}$ and $\mathrm{Mg}$, all of which is in agreement with previous findings (Py et al., 1987). Potassium and magnesium treatments had no significant effect on fruit $\mathrm{pH}$ or brix. There was no effect of the treatments on fruit quality of the ratoon.

Table 4 shows the effect of $\mathrm{N}, \mathrm{K}$ and $\mathrm{Mg}$ fertilizers on the size and core of the fruit. In the plant crop, increasing $\mathrm{N}$ from 224 to $392 \mathrm{~kg} / \mathrm{ha}$ significantly increased the length and width of the fruit. However, $\mathrm{K}$ and $\mathrm{Mg}$ application had no significant effect on these parameters. It is generally agreed that $\mathrm{N}$ fertilizer in pineapple is associated with fruit size, whereas $\mathrm{K}$ and $\mathrm{Mg}$ are associated with fruit quality (Py et al.,

TABLE 5.-D-lexf composition in the plant and the ratoon crops.

\begin{tabular}{|c|c|c|c|c|c|c|c|c|c|}
\hline & \multirow[b]{2}{*}{ Fertilizer } & \multicolumn{4}{|c|}{ 4-month-old plant crop } & \multicolumn{4}{|c|}{ 10-month-old plant crop } \\
\hline & & $\mathrm{N}$ & $\mathrm{K}$ & $\mathrm{Ca}$ & $\mathrm{Mg}$ & $\mathrm{N}$ & $\mathrm{K}$ & $\mathrm{Ca}$ & $\mathrm{Mg}$ \\
\hline & \multirow[t]{2}{*}{$\mathrm{kg} / \mathrm{ha}$} & & 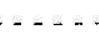 & 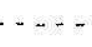 & ten & 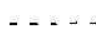 & . & 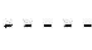 & $\ldots$ \\
\hline \multicolumn{9}{|c|}{ Nitrogen levels } & \\
\hline & 224 & 1.55 & 3.11 & 0.19 & 0.17 & 0.95 & 2.29 & 0.15 & 0.15 \\
\hline & 392 & 1.88 & 3.00 & 0.19 & 0.17 & 1.29 & 2.39 & 0.11 & 0.16 \\
\hline & 784 & 2.17 & 3.11 & 0.20 & 0.18 & 1.37 & 2.32 & 0.10 & 0.15 \\
\hline \multicolumn{10}{|c|}{$K_{2} \mathrm{O}$ and $\mathrm{MgO}$ levels } \\
\hline $\mathrm{K}_{2} \mathrm{O}$ & $\mathrm{MgO}$ & & & & & & & & \\
\hline 224 & 0 & 1.83 & 3.07 & 0.18 & 0.14 & 1.31 & 2.44 & 0.15 & 0.16 \\
\hline 224 & 56 & 1.83 & 3.00 & 0.17 & 0.18 & 1.25 & 2.27 & 0.13 & 0.16 \\
\hline 224 & 112 & 1.83 & 3.18 & 1.18 & 0.16 & 1.25 & 2.23 & 0.13 & 0.16 \\
\hline 224 & 224 & 1.76 & 2.85 & 0.18 & 0.16 & 1.18 & 2.26 & 0.12 & 0.17 \\
\hline 392 & 0 & 1.88 & 3.05 & 0.18 & 0.17 & 1.25 & 2.32 & 0.11 & 0.15 \\
\hline 392 & 56 & 1.93 & 3.07 & 0.17 & 0.18 & 1.20 & 2.27 & 0.14 & 0.17 \\
\hline 392 & 112 & 1.86 & 3.14 & 0.18 & 0.17 & 1.17 & 2.27 & 0.10 & 0.15 \\
\hline 392 & 224 & 1.81 & 3.18 & 0.16 & 0.17 & 1.12 & 2.33 & 0.13 & 0.17 \\
\hline 784 & 0 & 1.92 & 2.96 & 0.17 & 0.16 & 1.14 & 2.41 & 0.12 & 0.14 \\
\hline 784 & 56 & 1.91 & 2.92 & 0.16 & 0.16 & 1.19 & 2.43 & 0.12 & 0.14 \\
\hline 784 & 112 & 2.03 & 3.30 & 0.18 & 0.19 & 1.20 & 2.37 & 0.11 & 0.15 \\
\hline 784 & 224 & 1.84 & 3.17 & 0.18 & 0.18 & 1.22 & 2.39 & 0.11 & 0.16 \\
\hline
\end{tabular}


TABLE 5.-D-leaf composition in the plant and the ratoon crops. (Cont.)

\begin{tabular}{|c|c|c|c|c|c|c|c|c|c|}
\hline & \multirow[b]{2}{*}{ Fertilizer } & \multicolumn{4}{|c|}{ 22-month-old plant crop } & \multicolumn{4}{|c|}{ 26-month-old plant crop } \\
\hline & & $\mathrm{N}$ & $\mathrm{K}$ & $\mathrm{Ca}$ & $\mathrm{Mg}$ & $\mathrm{N}$ & K & $\mathrm{Ca}$ & $\mathrm{Mg}$ \\
\hline \multicolumn{2}{|r|}{$\mathrm{kg} / \mathrm{ha}$} & $\cdots$ & & & & & $\cdots$ & $-\infty$ & $\cdots$ \\
\hline \multicolumn{10}{|c|}{ Nitrogen levels } \\
\hline & 281 & 1.59 & 2.63 & 0.13 & 0.16 & 1.11 & 2.25 & 0.12 & 0.14 \\
\hline & 592 & 1.55 & 2.49 & 0.16 & 0.16 & 1.23 & 2.31 & 0.16 & 0.15 \\
\hline & 1267 & 1.89 & 2.50 & 0.17 & 0.17 & 1.60 & 2.29 & 0.15 & 0.14 \\
\hline \multicolumn{10}{|c|}{$\mathrm{K}_{2} \mathrm{O}$ and $\mathrm{MgO}$ levels } \\
\hline $\mathrm{K}_{2} \mathrm{O}$ & $\mathrm{MgO}$ & & & & & & & & \\
\hline 299 & 0 & 1.70 & 2.55 & 0.17 & 0.15 & 1.03 & 2.26 & 0.17 & 0.12 \\
\hline 299 & 93 & 1.71 & 2.49 & 0.16 & 0.16 & 1.32 & 2.19 & 0.13 & 0.14 \\
\hline 299 & 186 & 1.66 & 2.42 & 0.14 & 0.16 & 1.28 & 2.16 & 0.15 & 0.15 \\
\hline 299 & 372 & 1.61 & 2.43 & 0.15 & 0.17 & 1.33 & 2.17 & 0.16 & 0.15 \\
\hline 612 & 0 & 1.65 & 2.73 & 0.15 & 0.16 & 1.31 & 2.19 & 0.13 & 0.13 \\
\hline 612 & 93 & 1.79 & 2.65 & 0.14 & 0.16 & 1.29 & 2.32 & 0.12 & 0.14 \\
\hline 612 & 186 & 1.67 & 2.51 & 0.12 & 0.16 & 1.30 & 2.29 & 0.13 & 0.14 \\
\hline 612 & 372 & 1.66 & 2.54 & 0.15 & 0.18 & 1.30 & 2.20 & 0.13 & 0.16 \\
\hline 1304 & 0 & 1.75 & 2.65 & 0.16 & 0.15 & 1.29 & 2.44 & 0.13 & 0.13 \\
\hline 1304 & 93 & 1.63 & 2.70 & 0.17 & 0.16 & 1.34 & 2.35 & 0.14 & 0.14 \\
\hline 1304 & 186 & 1.62 & 2.63 & 0.16 & 0.17 & 1.39 & 2.34 & 0.12 & 0.14 \\
\hline 1304 & 372 & 1.65 & 2.51 & 0.15 & 0.18 & 1.30 & 2.46 & 0.14 & 0.15 \\
\hline
\end{tabular}

1987). No significant effect on fruit size was observed in the ratoon crop.

Pineapple D-leaf composition for both the plant and ratoon crops is summarized in Table 5 . The $\mathrm{N}$ and $\mathrm{K}$ content for 4-month-old plants was adequate. Nitrogen content increased as $\mathrm{N}$ application increased. Leaf $\mathrm{Ca}$ and $\mathrm{Mg}$ content was low in both young and old pineapple plants regardless of treatment. Potassium and magnesium absorption was not associated with the application of $\mathrm{K}$ and $\mathrm{Mg}$ fertilizer. This finding is difficult to explain on the basis of ion availability or ion antagonism effect.

On the basis of the results obtained in this experiment it would appear that $300 \mathrm{~kg} / \mathrm{ha}$ of $\mathrm{N}$ and $600 \mathrm{~kg} / \mathrm{ha}$ of $\mathrm{K}_{2} 0$ are required for a crop cycle of a plant and a ratoon crop of pineapple under the conditions prevailing at the study site. A definite response to $\mathrm{Mg}$ application was observed. On the other hand, on the basis of the D-leaf content of $\mathrm{N}, \mathrm{K}$ and $\mathrm{Mg}$, a responsible recommendation could not be made. More research is needed on levels of foliar applications of $\mathrm{N}, \mathrm{K}$ and $\mathrm{Mg}$ before final recommendations can be made. 


\section{LITERATURE CITED}

Cooke, P. C., 1949. The pineapple industry of the Hawaiian Islands. Dept. Fed. Malaya Johore Bahru.

González-Tejera, E, 1975. Effect of differential levels of N, K and Mg fertilizers on the fruit yield and quality of Ananas comosus L. (Merr.) vax: PR1-67. Proc. Amer. Soc. Hort. Sci. (Trop. Region) 19:147-58.

González-Tejera, E., H. R. Cibes y H. Gandía, 1974. El uso de abono nitrogenado y potásico con aplicaciones únicas y múltiples y su efecto en el crecimiento y la calidad de la piña (Ananas comosus L. Merr.) Var. PR1-67. Proc. Amer. Soc. Hort. Sci. (Región Tropical). 18:104-15.

Hernández-Medina, E., 1964. Magnesium an important nutrient in pineapple production in a Bayamón sandy clay. J. Agric. Univ. P.R. 48(1):17-24.

Hernández-Medina, E., 1961. Pineapple response to magnesium in Puerto Rico. Proc. Amer. Soc. Hort. Sci. (Trop. Region) 5:70-5.

Marchal, J., P. Martin-Prevel, J. J. Laccoeuilhe et P. Lossois, 1970. Recherche d'un equilibre $\mathrm{K} / \mathrm{N}$ dans la production de l'ananas frais au Cameroun. 11. Analyses foliaires. Fruits 25:87-95.

Martin-Prevel, P., 1961a. Potassium, calcium et magnesium dans la production de l'ananas en Guineé. I. Plan et déroulement de létude. Fruits 16:49-56.

Martin-Prevel, P., 1961b. Potassium, calcium et magnesium dans la nutrition de l'ananas en Guineé. II. Influence sur le rendiment commercialisable. Fruits 16:11323.

Martin-Prevel, P., 1961c. Potassium, calcium et magnésium dans la nutrition de l'ananas en Guineé. IV. Etude de la croissance folliare. Fruits 16:341-51.

Py, C, J. J. Lacoeuilhe and C. Teisson, 1987. The Pineapple: Cultivation and Uses. Editions G. P. Maisonneuue and Larose, Paris. pp. 188-91.

Samuels, G., S. Alers-Alers and G. Jackson, 1958. Influence of fertilizers on yields of pineapple on a Coto clay. J. Agric. Univ. P.R. 42(1):12-26.

Samuels, G., P. Landrau and R. Olivencia, 1955. Response of pineapple to the application of fertilizers. J. Agric. Univ. P.R. 39(1):1-11.

Siders, C. P. and H. Y. Young, 1946. Effects of nitrogen on growth and ash constituents of Ananas comosus (L.) Merr. Plant Physiol, 21:247-70.

Siders, C. P. and H. Y. Young, 1945. Effects of different amounts of potassium on growth and ash constituents of Ananas comosus (L.) Merr. Plant Physiol. 20:609-30.

Teiwes, $\mathrm{G}$, and $\mathrm{F}$. Gruneberg, 1963. Science and practice in the manuring of pineapples. Green Bulletin 3. 